goes according to plan, anyone will be able to order an off-the-shelf mutant mouse to test any biological hypotheses or develop any disease model.

The consortium formally launched itself earlier this month with the signing of a cooperation agreement between three funding agencies that together are committing several hundred thousand dollars to the cause over the next five years or so: the European Commission, the US National Institutes of Health and Genome Canada. The signing took place during a two-day meeting organized by the European Commission at a lakeside chateau in Genval, a village just outside Brussels, where delegates from around the world were able to discuss the implementation of the ambitious plan and to dream about the next steps.

The practicalities don't depend only on money. Databases are needed so that the consortium can efficiently share information and avoid duplication. The most important mutants need to be 'phenotyped', or characterized, to record the physiological effects caused by the lack of a gene. This means expanding and standardizing the activities of the 'mouse clinics' that have sprung up, mostly in Europe, to support previous research programmes. The question of how much phenotyping needs to be done during this phase, and on how many of the chosen mutants, still remains to be resolved.

Grandiose as these plans are, they are but one major step towards the vision of offering an even fuller service to biologists. For example, most of the embryonic stem-cell mutants currently available are 'null' knockouts - the targeted gene simply doesn't function. But, at a greater cost, it is now possible to make 'null-first conditional-ready' mutants. In these, the gene is knocked out by default but can be reestablished and knocked out at will in particular tissues at particular times. This flexibility is much more valuable to researchers.

This technology cannot currently be applied to all genes, but it is developing fast. A fuller service would require that more extensive phenotyping be done on each of the mutants. Moreover, a further database is required to document the differences between mouse and human gene function, to ensure a deeper understanding of mouse models of human disease. The full service will be costly.

This vision represents the fulfilment of mouse genome sequencing. Support for that project needs to be followed through: the mouse has already led to excellent insights into many human diseases, and the continuation of this approach will deliver many more. Budgets have tightened, but funding agencies that stay the course can be assured of ample returns on their investment.

\section{Cut the climate antics}

\section{A long run of congressional theatre should close.}

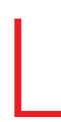

ast week, Al Gore made a triumphant return to Washington, testifying in the US Congress for the first time since his film, An Inconvenient Truth, turned the man who was almost president into an Oscar-winning environmental saint. He is now reckoned by almost everybody to have been right all along, and his star turn could mark the moment when Congress gives up arguing about whether climate change is real, and starts arguing about how to handle it.

The affair was suitably raucous, with a burst of camera shutters punctuating the former vice-president's every gesture and scribbling journalists packed in so tight they had to keep their elbows in front of them. Looking solid but progressive in a blue-checked shirt and blue tie, Gore called on Congress to be bold on climate change. "There is a sense of hope in this country that this Congress will rise to the occasion," he said. "We do not have time to play around with this."

Gore also made specific recommendations for action, suggesting changes that are probably too bold for any sitting politician but that may expand the outer bounds of what is considered feasible. They included freezing emissions levels immediately, then reducing them by $90 \%$ by 2050 ; a carbon tax and a cap-and-trade scheme; bans on incandescent light bulbs and new coal plants that cannot be made to capture and store carbon; corporate disclosure of carbon emissions; and tougher mileage standards for cars.

The leading Republicans in the committees where he spoke kept up their increasingly surreal insistence that climate change isn't happening. Joe Barton of Texas in the House of Representatives and James Inhofe of Oklahoma in the Senate not only presented increasingly threadbare arguments against climate change, but seemed to be trying to take the lustre off the occasion by extensively negotiating how much time they would get to speak.

Inhofe was so determined to get his share of the time that he wanted Gore to respond to all his questions in writing only. He was overruled by Barbara Boxer, the Democrat senator from California who now runs what used to be Inhofe's committee in the Senate and clearly relishes it - at one point she brandished her gavel at him triumphantly. Gore responded to their questions with scientific lectures, deep sighs and offers of one-to-one tutoring in climate science.

More productively, most Republicans asked Gore substantive questions about policy approaches, notably on the challenge of convincing China and India to act, and on the possibility of a renaissance for nuclear power (Gore is wary of it, being an ardent fan of distributed micro-generation). Some Republicans seemed willing to make it their issue too. Republican stalwart Senator John Warner of Virginia said: "I am prepared to fight with you on this." In the House, Bob Inglis of South Carolina framed it as a Christian issue and said that efforts should be made to cut down emissions even without China and India because "you teach your children to do the right thing, even if no one is looking".

In the metro system beneath the Capitol complex, Boxer said that Gore was pleased with the Republican response. As she chatted with reporters, Gore dashed to an adjoining carriage. As the doors threatened to close on him, a Capitol worker reached out and held the door for him. Boxer watched in astonishment. "I've never seen them do that for anyone before," she said.

It was all good theatre, but the high jinks of the climate-change sceptics already seem outdated, and many in their own party are starting to ignore them with the serene expression seen on the faces of parents when their children throw a temper tantrum in public. This is the duty of all sensible politicians as they move forward on climatechange policy. The naysayers should be indulged no longer. 